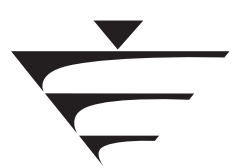

\title{
Erratum: The Cullochy weir breach and weir reconstruction
}

Andrew W. D. Ross BSC (Hons), CEng, MICE

Technical Manager, Scottish Canals, Inverness, UK

(andrew.ross@scottishcanals.co.uk)

The publisher regrets that the following errors appeared in this paper when it was published in Dams and Reservoirs 27(1): 24-35.

The below statements are the correct statements. They were published incorrectly in the original paper.

'A $35 \mathrm{~m}$ length of the canal embankment had been washed away, together with the downstream face of the $57 \mathrm{~m}$ long Cullochy Weir.' p25

'However, as the temporary dam was completed, the flow through the porous rock dam was significantly less than the uncontrolled breach flow, and the water level began to rise.' $\mathrm{p} 28$

'The following morning, 29 April 2015, the pontoons and the long-reach excavator were pushed by a tug (also delivered to Fort Augustus on a fourth articulated lorry), via Cullochy Lock (Figure 9), to the temporary dam site at the old Aberchalder Bridge.' p30
'However, alternative access for pedestrians and cyclists using the Great Glen Way, and the National Cycle Network Route 78 between Aberchalder Swing Bridge and Cullochy Lock, is along the opposite towpath on the south side of the canal.' p30

'An alternative vehicle access to the holiday cottage on the north-east side of Cullochy Lock is along the canal towpath from Fort Augustus.' p30, 31

'The majority of the sands, gravels and cobbles that were washed out of the Cullochy Weir and the adjacent canal embankment, ended up a short distance downstream in the River Oich.' p31

'A significant volume of timber debris was thought to have been washed into the Caledonian Canal from Loch Oich at the time of the flood, judging by the trees and branches that wedged between the top of the upstream lock gates and the underside of the cross-lock walkway at the nearby Cullochy Lock.' p33 